\title{
Entrepreneurship Theory: \\ New Challenges and Future Prospects
}

\section{Alexander Chepurenko}

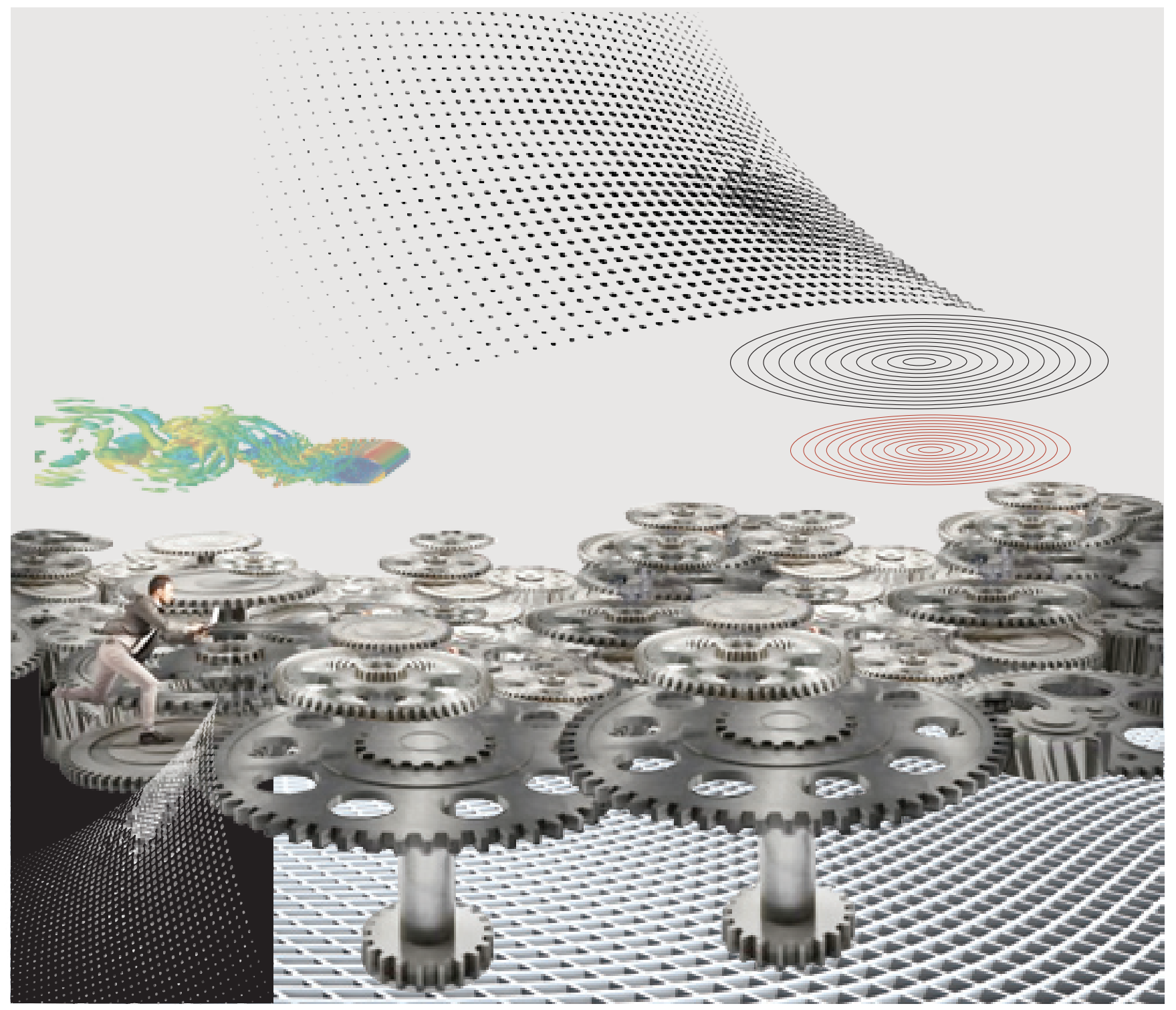

To enable the sustainable development of the entrepreneurship theory its agenda needs comprehensive adjustments, and refocusing on new areas such as social, institutional entrepreneurship, etc. Research in the field should go beyond Western societies, covering the so-called transitional economies and emerging markets

There are some very important contextual differences between these societies, which make the entrepreneurship specific and make the investigation of new institutions and actors important, which might become challenging subjects of the future entrepreneurship theory.
Alexander Chepurenko - Professor, Faculty of Social Sciences; Head, Department of Economic Sociology; Laboratory Head and Academic Supervisor, Laboratory of Entrepreneurship Research and Faculty of Social Sciences. E-mail: achepurenko@hse.ru

National Research University - Higher School of Economics Address: 11, Myasnitskaya str., Moscow 101000, Russian Federation

\section{Keywords}

entrepreneurship theory; methodology; Russia; innovation entrepreneurship; social entrepreneurship; institutional entrepreneurship

DOI: 10.17323/1995-459X.2015.2.44.57

Citation: Chepurenko A. (2015) Entrepreneurship Theory: New Challenges and Future Prospects. Foresight-Russia, vol. 9, no 2, pp. 44-57. DOI: 10.17323/1995-459x.2015.2.44.57. 
E ntrepreneurship research is certainly one of the most dynamic areas within the cluster of socio-economic and managerial sciences in the last 2025 years. This statement can be confirmed by the list of renowned international conferences held on related issues annually, the number of participants in these conferences, as well as by the growing number of leading international journals publishing on entrepreneurship.

The significance of the field was acknowledged by the launch in 1995 of the Global Entrepreneurship Research Award. This award has to date been bestowed upon more than two dozen outstanding thinkers who have had a big impact on the discipline of entrepreneurship, including David Birch, Bill Gartner, Scott Shane, Paul Reynolds, Isaac Kirzner, William Baumol, David Audretsch, Bengt Johannisson, Zoltan Acs, Josh Lerner and some other prominent scientists [HSE, 2013]. Moreover, one of them - William Baumol - was nominated for the Nobel Prize in Economics in 2014.

However, some questions concerning the self-legitimation and the future development of the field remain. The paper deals with the long-term prospects for entrepreneurship research.

First, there is the question of identity. Is entrepreneurship theory a well-established area of research or is it instead a field of intervention undertaken by representatives of economics, management, or social theory? The answer to this question depends on the definition of entrepreneurship theory. This paper argues that a new definition of entrepreneurship theory developed in the last decade may lead to not only a major conceptual shift but also to entirely new directions of research in other areas of the social sciences, which could be called the entrepreneurship research driven imperialism, its penetration into rather new areas of social research.

Second, our new knowledge on entrepreneurship is mostly derived from analyses of well-functioning and sustainable market economies. Are the approaches, concepts and the results in particular of such a 'Western-centric' theory relevant for other types of environments? What are the implications of broadening our geographical view?

Third, a research project's content, research methods, and organizational design may change because of developments in the IT industry. The ever-increasing penetration of social media may also offer new opportunities. To be entrepreneurial, entrepreneurship research should explore and use such opportunities.

Lastly, the audience of entrepreneurship research may also change. Now academicians, MBA students, and policy-makers benef it from the findings of entrepreneurship research. However, the situation is rapidly evolving, and new groups may become the recipients of entrepreneurship research.

It is the questions posed above that are discussed in the remainder of this article. We start with a short overview of the state of the art, then, we provide a short Foresight exercise of the prospective areas, actors, and research design of entrepreneurship theory in the future. A separate section is dedicated to entrepreneurship research in Russia. The article concludes with a discussion of fruitful avenues for further research in entrepreneurship.

\section{State of the art and the identity problem}

Since the 1980s, entrepreneurship has become a point of interest for many researchers in neighbouring fields, including management, economics, sociology, and psychology. First, following research that showed that small and medium sized enterprises (SMEs) create no fewer jobs than large firms, it became clear that the 'reevaluation of the role of small firms is related to renewed attention to the role of entrepreneurship' [Wennekers, Thurik, 1999, p. 28-29], as SMEs that establish new jobs are entrepreneurial 'by definition'. Later, another approach was suggested to explain the greater interest in entrepreneurship. This approach differentiated between managerial and entrepreneurial economies to identify the links between a post-materialist society and the new role of entrepreneurial activity in this context [Audretsch, Thurik, 2000; Uhlaner, Thurik, 2007]. 
The issue is less related to the post-materialism paradigm itself, and more related to the accompanying slowdown in the global economy in the last decade. Additionally, there is evidence that the fifth long wave of economic development is entering its final stage [Hargroves, Smith, 2005]. Only entrepreneurial creativity can help to speed up the growth of gross domestic product (GDP) and secure a stable increase in the wellbeing of nations.

Second, the rapid development of empirically based entrepreneurship research in the 1980s and early 1990s was in many ways inspired by the rising demand for entrepreneurship and/or leadership programmes in the business schools of leading Anglo-Saxon universities. Therefore, since then the entrepreneurship division has been one of the top sections in the Academy of Management in the USA based on the number and intensity of its members. Undoubtedly, such a close link to business schools had, and continues to have, a considerable impact on the character of research, which was primarily oriented on two core problems: who starts up a new business, and what are the (non-financial) pre-conditions of successful business growth? In that light, entrepreneurship research could be understood as an integral part of management.

Meanwhile, the development of the field in the 1980s was quite extensive. In the mid-1990s, another important factor influenced research on entrepreneurship. This was the transition of the economic system of several former socialist countries in Asia and Europe. Transitional studies from the very beginning brought new insights to the field of entrepreneurship. The path dependence paradigm soon transformed into a more precise study of entrepreneurial contexts in the new market economies and the influence of the institutional environment on the specifics of the performance of SMEs and of entrepreneurial strategies [Earle, Sakova, 2000; Smallbone, Welter, 2001; Ovaska, Sobel, 2005; Smallbone, Welter, 2009; Aidis et al., 2010; Welter, Smallbone, 2011]. Second, the success of international, longitudinal projects such as the Panel Study of Entrepreneurial Dynamics (PSED) (and the Global Entrepreneurship Monitor (GEM) has meant that vast quantities of reliable, quantitative data are now available for comparative research on early entrepreneurial activity across nations [Reynolds et al., 2005]. Third, the idea of a contextual approach [Welter, 2011] won many supporters; societal and social framework conditions and their impact on entrepreneurship became a focus of many projects and publications.

As a result, the field was characterized by spectacular growth, and the set of topics and theoretical concepts used in the literature widened significantly during the first decade of the $21^{\text {st }}$ century [Busenitz et al., 2003; Uhlaner, 2003; Ireland et al., 2005; Xheneti, Blackburn, 2011; Carlsson et al., 2013]. Moreover, other researchers have analysed the achievements in particular areas, such as social entrepreneurship [Dacin et al., 2010], sustainable entrepreneurship [Hall et al., 2010], cross-cultural entrepreneurship research [Engelen et al., 2009], entrepreneurship in emerging economies and developing societies [Naudé, 2010; Kiss et al., 2012], and methods in entrepreneurship research [Short et al., 2010]. Now entrepreneurship research seems to be theoretically well supported. Broadly accepted theories exist at all levels (macro, mezzo, and micro) and are supported by various core scientific domains.

However, as research studies have become more longitudinal and more intensive, it has become evident that not all (small) firms are entrepreneurial firms (see for example, [Shane, 2009]). The majority of firms are unable to survive, with growth being the exception rather than the rule. Similar problems emerge when researchers try to link entrepreneurship theory with innovation. Innovation is not an intrinsic attribute of every firm; hence, many activities of new ventures and already established businesses would be ignored when using such a theoretical framework. The same is true when speaking about the establishment of new organizations, as in this case the development of already existing firms does not matter. Hence, a reconsideration of the field's definition is needed to remove 'political and methodological biases' [Nightingale, Coad, 2013].

Nevertheless, at the beginning of the last decade some debates around the core questions of the field occurred. First, the question of legitimacy: is entrepreneurship research a separate field, or rather a sub-field of research in more traditional areas? It is argued that any attempt to view entrepreneurship as some- 
thing combined with (only) the creation and growth of small firms leads to a clear recognition that entrepreneurship is a sub-field of strategic management [Shane, Venkataraman, 2000, 2001].

Besides, every mature field of research seeks legitimacy, which is achieved when it moves from phase 1 ('pre-paradigm') to phase 2 ('normal science'). This transition to phase two is based on a widespread consensus about the appropriate methods, terminology and the kinds of experiments that may contribute new insights [Kuhn, 1962]. It is also important because such a consolidation is key for defining possible areas which may lead to new insights and research methods. The possible answer that we tend to accept and support is that the entrepreneurship research can be understood as a homogeneous field primarily in terms of the phenomenon of the 'emergence of new economic activity'. As a starting point, it is broad enough to cover different forms of establishing new economic activity; it implies the usage of different methods; it is appropriate in economic, social and behavioural sciences; and finally, it embraces micro, mezzo, and macro-levels of analysis.

However, in this case, not all aspects related to already established businesses with the exception of intrapreneurship - refer to entrepreneurship research. On the other hand, several phenomena in other areas can be the subject of entrepreneurship research. These include social entrepreneurship [Lyon, Sepulveda, 2009; Choi, Majumdar, 2014], ecological activity to secure the earth's resources [Patzelt, Shepard, 2011; Parrish, 2010], and a theory bringing challenging insights into the understanding of human behaviour [Shane, 2009] and its logic [Sarasvathy, 2001].

Second, a discussion about the concordance between conceptual definitions of key phenomena and empirical observations might have some importance for empirical research in the field. We already have a wide range of proven methods to study entrepreneurship as the 'creation of new organizations' [Gartner, 1988]. However, we lack methods to collect empirically robust data on entrepreneurship defined as the 'creation of new economic activity' [Davidsson, Wiklund, 2001] or 'opportunity discovery and exploitation' [Shane, Venkataraman, 2000].

\section{Prospects for entrepreneurship research as a field: prospective areas, actors, and research design}

A theory can be manifested as a substantive field on its own within the scope of the social sciences if it is has a more or less consensual approach to the main research objectives, and shared views on the most fruitful research methods and expected outcomes. The same approach should be used when discussing the prospects of entrepreneurship as a theory.

The research area is defined by the sort of research questions that form a starting point of any new research project in the field. Following Shane and Venkataraman [Shane, Venkataraman, 2000], the fundamental starting points in entrepreneurship research could be formulated as follows: 'how, why, and when do entrepreneurial firms discover and exploit opportunities?'

Such an approach enables an intervention in subjects beyond the narrowly defined commercial areas, such as social entrepreneurship [Austin et al., 2006; Mair, Marti, 2006] and its impact on the design of state-society relations; and institutional entrepreneurship [Greenwood, Suddaby, 2006; Maguire et al., 2004] and its impact on the role of traditional sources of institution building (state, civil society).

Moreover, the paper deals with some unavoidable trends in future entrepreneurship research, resulting from a geographical expansion (encompassing the former socialist economies, and countries in the global south and east) and involving the entrepreneurial actions of people with totally different sets of resources, capital, and societal norms.

\section{New areas}

Entrepreneurship research was born in steadily developing, Anglo-Saxon market economies as a reflection of the dominating ideology of creativity, risk-taking 
ability, and the need to achieve on a personal level, and the growth aspiration and profit drive of private commercial firms. The concepts of the role of entrepreneurship [Schumpeter, 1936] and the driving motives of an entrepreneurial human being [McClelland, 1961] are abstractions that are characteristic of this group of societies, with their inherent forms of economic development.

However, in the contemporary world, there are new areas where entrepreneurship, in the sense in which we defined it above, is becoming increasingly important. First, there are poor countries with resource-driven economies (according to the World Economic Forum, WEF). In these countries, the exploration and exploitation of opportunity become a single possibility to secure a more or less acceptable wellbeing. As the data of the GEM for a several years show, the level of engagement in entrepreneurship is much higher in poor, resourcedriven economies than in established market economies. Of course, in this case we see another kind of entrepreneurship - one driven by necessity rather than by opportunity, often based on social capital, and one where entrepreneurs' economic and human capital is rather limited. Hence, its specifics can only be understood within the existing framework conditions in these societies. For example, extended families and their resources play a significant role in establishing entrepreneurial ventures; remittances (immigrant money transfers to the home country) are important as a source of financing for domestic businesses; and the specifics of female entrepreneurship as a chance to become semi-independent from male dominance and household labour. All these factors may be of significant interest and importance to understand the chances and constraints of entrepreneurial activity in these countries. Besides, the big differences between the various countries in this group also influence the speed and type of entrepreneurial development. Above all, the type of state policy serves as a framework for the development of private ventures: for example, we can identify the Royal Cambodian model, the Doi-Moi model, and others [Dana, 2007]. However, to date only a few books and papers have been published and look at entrepreneurship in these economies [Fick, 2002, 2014; Naudé, 2010; Herrington, Kelley, 2013; Simons, 2012].

The second area of rapid growth of a non-Anglo-Saxon entrepreneurship model is in the developed Asian societies such as Japan and the new Asian tigers. Embedded in a strong state-dominated framework, the attempts to build an entrepreneurial community in Japan, the enlightened dirigiste political leadership in Singapore, or the crisis-driven developments in South Korea have had a massive impact on the formation of entrepreneurial strategies and visions of entrepreneurial success [Dana, 2007].

The third new area of entrepreneurship development is in countries undergoing a process of systemic transition. At the beginning of the process of systemic changes, most experts were very enthusiastic about the prospects for a market economy and democracy in countries of Central and Eastern Europe (CEE) and the Commonwealth of Independent States (CIS). The boom of the bottom-up, 'Schumpeterian' entrepreneurship seemed to become an evident inception stage and the inevitable condition of any modernization of economies and societies. Privatization should establish pre-conditions for it, and the transfer of Western experiences in, for example, SME policy was assumed to support a rapid development of newly established businesses. However, by as early as the mid1990s, it became clear that the intensity of entrepreneurial start-ups and the entrepreneurial activity of the population overall were lower than expected in most of these countries.

As recognized by experts, privatization has not created more possibilities for entrepreneurship. Instead, in many post-socialist economies, privatization enabled a seizure of the most efficient assets either by the former 'nomenclature' or by large transnational companies, and led to so-called 'predatory entrepreneurship' [Feige, 1997; Spicer et al., 2000; Scase, 2003]. Top-down created businesses appeared as a result of redistribution of former state-owned assets by political entrepreneurs using their informal connections with some decision-makers [Rehn, Taalas, 2004]. In contrast, the majority of bottom-up entrepreneurs (mostly micro and small firm owners or solo entrepreneurs, termed 'proletarian' businesses here because they do not own a significant portion of the resources that they 
use) continue to rent their production facilities and other material resources, even after 20 years. Their income is insufficient to buy out their premises.

Despite the more than two decades of systemic changes in the CEE and CIS countries, entrepreneurship under 'transition' is still under-investigated. Fruitful research attempts should study this phenomenon in different (and diverging) contexts of 'transition'. The most challenging questions are:

- How the interplay of formal and informal institutions and networks influences different models of entrepreneurial behaviour [Rehn, Taalas, 2004; Batjargal, 2006];

- The role of 'institutional traps' emerging in the process of transferring institutions and 'best practices' (some research has been carried out on the evolution of SME and entrepreneurship policy under 'transition': see, for example, [Smallbone, Welter, 2001]), and how these 'institutional traps' are reflected in weak outcomes of entrepreneurship in some of these countries;

- The variety and heterogeneity of productive, unproductive and even destructive entrepreneurial types under 'transition' [Rona-Tas, Sagi, 2005; Sauka, Welter, 2007].

Quantitative measurements need to be embedded into theoretical explanatory models that are based on qualitative analysis of the specifics of entrepreneurial and not on geopolitical presumptions (EU versus non-EU membership etc.). Some concepts of new institutional theory, such as different types of 'access orders' [North et al., 2010] and different types of entrepreneurial behavior, may be useful to recognize the specifics of entrepreneurship performance within different institutional settings.

Furthermore, it is evident that the economic and socio-political systems of the 'transitional' economies and societies, as well as their entrepreneurial profiles [Smallbone, Welter, 2001; Ovaska, Sobel, 2005], are increasingly diverging. In fact, the term 'transition' now seems to conceal more than it reveals. Today, the term 'transition countries' is not a homogeneous group but rather a geopolitical label. In fact, the so-called 'common past', which shaped similar entrepreneurial framework conditions (EFC) at the start of the systemic 'transition', was rather an oversimplified idea. In reality, despite some commonalities, socialist economies and societies showed as many differences as there exist between the so-called 'Western' economies and societies, so it is appropriate to consider the 'varieties of socialism'. Moreover, the trajectories of transition made by these countries differed from the very beginning.

The fourth new area of entrepreneurship development is in contemporary China and India. The rationale for inclusion is not only because of the current incremental growth of entrepreneurial ventures (and especially the more intensified growth expected in these countries in the nearest future) [Khanna, 2008], but also because both these countries cannot be understood within the paradigms of 'transition' or 'third world'. China is not a transition economy as the introduction of market institutions is managed by the communist party which preserves political dominance. According to [Jonas et al., 2013], entrepreneurship in China is very different to that found in Western economies in several ways. First, entrepreneurs who succeed in China have mastered 'integrated innovation': the skill of re-inventing any existing business idea to meet the demands of Chinese consumers. Often starting with Western-styled products, after many iterative steps of localization the end product differs significantly from the initial one. Second, Chinese entrepreneurs have a deep knowledge of the specifics of the Chinese economy which remains relatively closed to the rest of the world. Nevertheless, Chinese citizens continue to find ways to circumvent barriers and procure ideas from abroad, creating pent-up demand for new goods and services. Successful entrepreneurs are filling these gaps. Finally, Chinese entrepreneurs are aware of political constraints and are always aware of the possibility of government intervention. To avoid undesirable policy changes, some choose to enter lightly regulated sectors, while others try to comply with the five-year procurement plans. To date, we have little reliable empirical data on the development of entrepreneurship in China, and few academic papers deal- 
ing with the specifics of the Chinese ecosystem of entrepreneurship where formal and informal networks may play an important role [Wong et al., 1995; Liao, Sohmen, 2001; Zhang et al., 2006].

India is a country with high inequality and a large share of poor population, and yet its economy is growing in a much more dynamic and impressive way than in most developing countries. Moreover, the co-existence of necessity driven entrepreneurship [Sridharan et al., 2014], especially among women [Torri, Martinez, 2014], under the predominance of the caste system in rural areas [Folmer et al., 2010] and the clusters of modern, dynamic entrepreneurial firms in urban agglomerations are challenging topics for prospective research [Koster, Kumar Rai, 2008; Monsen et al., 2012].

Besides the geographical broadening, there are other dimensions to the expansion of entrepreneurship research that go beyond the narrowly defined commercial aspects, such as social entrepreneurship. The development of this form of entrepreneurial approach to social problems has a twofold nature: first, the embedding of ideas of social responsibility, tolerance and solidarity into the middle classes in Western societies; second, a serious shortage of state budgetary funding to tackle urgent social problems both in Western and poorer countries of the world particularly. This empowers social entrepreneurs to influence the design of a new system of state-society relations. Features of this trend are ecopreneurship, driven by the idea of sustainable economic development and decreasing resources consumption, and institutional entrepreneurship.

Eisenstadt first used the notion of 'institutional entrepreneurship' [Eisenstadt, 1980]. DiMaggio used the term to characterize actors with sufficient resources to contribute to the genesis of new institutions in which they see 'an opportunity to realize interest that they value highly' [DiMaggio, 1988, p. 14]. However, the interplay between institutional entrepreneurship and the mainstream types of entrepreneurship has not been sufficiently studied. Some authors [Phillips, Tracey, 2007] have argued that an intensive dialogue is needed between these two traditions. Namely, a promising strand of future research would further examine not only how existing institutional arrangements influence entrepreneurship activity, but also how entrepreneurs can shape those arrangements. This issue is especially promising when looking at emerging market economies.

\section{New actors}

As the mainstream literature on entrepreneurship is based on both the facts as well as social and societal patterns of Western - particularly of Anglo-Saxon societies, it usually assumes that an entrepreneur is an 'Anglo-Saxon' (sharing Protestant values, driven by opportunities) and who operates in a mature market economy and democracy. The single exclusion is an immigrant, or ethnic entrepreneur, but even he/she is trying to use resources and capital available to them to establish a sustainable business which would enable him/her to integrate into the host economy and society.

However, in the future, as entrepreneurial practices from beyond the area of traditional entrepreneurship research are integrated, the research approach will have to undergo unavoidable changes. These entrepreneurial practices are in 'other worlds' where different societal norms and values dominate, the market economy is less sustainable, and political regimes are either rigid or fragile. The new approach should take into consideration that when exploring and exploiting opportunities, people do not always have growth and wealth creation as their ultimate goals and criteria of success; that a high level of informality will be inherent and remain a long lasting strategy rather than an episode in processes of creating start-ups; that different incentives to become entrepreneurial may play important roles (for instance, independence from the clan or family, or further immigration, etc.); and that the concept of unproductive and destructive entrepreneurship [Baumol, 1990] may become quite important to understand the business behaviour and pragmatic strategies of entrepreneurial firm owners.

Another new important actor could be the 'olderpreneur', or an entrepreneur who entered into a new business after the age of 50. Current entrepreneurship research is primarily focused on young and well-educated actors in start-ups. 
However, the world is changing: societies are ageing rapidly and improvements in wellbeing and healthcare have an impact on both the possibility (including through increasing the amount of accessible financial sources) and the ability and motivation of older people to explore entrepreneurship as a new opportunity. Until now, this entrepreneurial cohort has been under-investigated [Curran, Blackburn, 2001; Vickerstaff, Cox, 2005; Mallett, Wapshott, 2015].

Semi-skilled IT-entrepreneurs might become the third new actor in the field of entrepreneurship in the immediate future. To date, entrepreneurship in high tech industries has been understood primarily as a domain of well-educated techno-starters. Yet because of the level of IT technology already achieved, some IT-based entrepreneurship does not always require as high a level of specific knowledge and skills as in the past. For instance, in businesses using IT technologies as a 'black box' to improve selling practices or logistics, having a high level of alertness and a native born ability for effective management behaviour is much more important. Hence, some creative entrepreneurs who do not possess advanced knowledge about new technologies yet have a feeling for new niches and options in the development of virtual services and solutions can become successful and create another cohort of entrepreneurs.

Furthermore, new forms of labour relations and the rise of freelancing provide incentives for many freelancers to create their own business. Traditionally, the literature considers freelancing as an innovative form of professional career [Dyer, 1994; Bögenhold et al., 2014]. Yet, the transition from a typical 'portfolio' career to business is a rather new field of research. We assume that in the near future interest in longitudinal studies looking at the transformation from selfemployed to entrepreneurs will become more important.

New social technologies as well as the penetration of entrepreneurship into traditional societies should also attract researchers' attention to forms of start-up financing which have hardly been investigated before, such as crowdfunding in established market economies [Tomczak, Brem, 2013; Fraser et al., 2015] or Islamic banking and its role in the development of entrepreneurship in Muslim societies. We are confident that the expansion of crowdfunding practices, above all in social entrepreneurship [Lehner, Nicholls, 2014], and in start-up financing [Frydrych et al., 2014] will shift the focus of analysis of lending practices to a relatively new group of portfolio investors [Belleflamme et al., 2013]. These investors belong neither to the cohort of professional business angels, nor to the famous '3Fs' (friends, family, and fools) as they would expect a certain reward on their investment and compare this future reward with the reward from alternative investment possibilities.

The expansion of Islamic banking in Muslim countries in the last few decades has been spectacular. Nonetheless, only a few papers have been published that examine the role of this specific system of risk and profit sharing between the bank and its clients in entrepreneurial ventures. These studies are mostly concerned with explaining the moral and philosophical foundations [Baki Adas, 2006; Elfakhani, Ahmed, 2013]. There is a huge shortage of empirically based studies on the financial infrastructure for entrepreneurship in Islamic countries ('Sharia compliant finance') and its impact on entrepreneurs' attitudes toward the uncertainties and risks associated with their business strategies.

\section{Research design and methods}

Entrepreneurship research must also address some design and methodological challenges. First, despite some very successful projects which have produced a lot of comparable empirical data (such as the aforementioned GEM and the PSED), we still have a shortage of longitudinally designed projects. Therefore, entrepreneurship research has to make do with predominantly cross-sectional research designs, which produce non-cumulative and inconsistent findings. Meanwhile, entrepreneurship research has become increasingly international and the most interesting studies are based on intensive cooperation between scientists from different countries and continents. A certain level of collective trust and a shared approach to the expected outcomes of empirical studies would help more collaboration develop, at an institutional level as well. We expect that 
in the future, international organizations, consortia of leading business schools, and business associations would collaborate on longitudinal projects. Such projects would have a significant impact on research, education and on the development and implementation of policy recommendations for fostering entrepreneurship internationally.

The internationalization of research projects will push researchers to become more interdisciplinary in their approach to data analysis. The reason is that the biggest problem of any comparative study is insufficient understanding of the socio-political and economic contexts of the data. There is no value in comparing non-comparable phenomena: entrepreneurship in established market economies vs. entrepreneurship in 'transitional' societies or emergent markets. More inter-disciplinary wisdom would be needed for a deeper understanding of societal norms, traits and attitudes, and the typical economic practices governing in different environments.

The fact that some new areas of entrepreneurship research will show significant qualitative changes in their framework conditions in the future - and consequently, changes in the forms of entrepreneurial activities and business norms and strategies - means that more good qualitative research (case studies, panel studies, etc.) will be needed.

The subjects of research are not alone in expecting changes in the future; we expect the methods for doing research on entrepreneurship to also alter in the future. 'Big data' mining [Dahl, 2010; Tirunillai, Tellis, 2014] and 'single source' [Cannon et al., 2007; Petrescu, 2013] methods from marketing research will become widespread in entrepreneurial research. Moreover, focused enactive research [Haskell et al., 2002] — not necessarily in the form already used in entrepreneurship literature [Johannisson, 2011; Fletcher, 2011; Steyaert, Landström, 2011] — will be used instead to create and moderate special focused groups in social media [Cooke, Buckley, 2008]. This kind of enactive research would enrich the palette of methods to discover the attitudes, perceptions, and self-representations of entrepreneurs.

Hence, more collaboration with different commercial providers of household and individual data (for example, data on consumer behaviour and expenses, financial strategies, economic engagement, attitude towards advertising) would bring new insights into entrepreneurial activities and entrepreneurs' behaviour, entrepreneurs' motives, and existing constraints. This approach would reduce the need for expensive empirical surveys, yet ethical questions concerning the research remain. It is much easier to guarantee the anonymity of respondents through data collected via traditional surveying than to provide data confidentiality when accessing the databases of market researchers [Nunan, Di Domenico, 2013].

\section{New audience}

To date, the audience of entrepreneurship research results has been quite traditional: academics, policy makers, entrepreneurs, and students. However, as entrepreneurship research is likely to encompass areas connected to other types of activities in the future, especially the third sector, some of the findings (in particular, the social implications of entrepreneurship, and the innovative practices of social and institutional entrepreneurship) might be of interest for a broader audience. Consequently, the definition of 'entrepreneurship' itself would be subjected to a certain amount of change.

Demand for new communication tools and platforms is growing (not only academic and business journals, or briefings for media and policy makers, but also social media). Furthermore, entrepreneurship researchers themselves should be prepared to become involved as policy advisors and in policy-making processes.

\section{Entrepreneurship research in Russia: challenges}

Entrepreneurship theory in Russia is under-developed. There are neither scientific journals nor conferences, and only very rarely do articles appear in lead- 
ing journals in economics, management or sociology. At an institutional level, there are no centres of excellence which would carry out on a permanent basis research on entrepreneurship and provide methodological and organizational support for educational programmes in universities. Even in the area of applied research and policy advising, there are only 2-3 active institutions with a sufficiently high level of professional expertise. The achievements of international entrepreneurship research remain either unknown or ignored (with a few exceptions including [Chepurenko, Yakovlev, 2013; Chepurenko, 2013a, 2013b]. Often, entrepreneurship is not recognized as an academic discipline and instead only seen as a contingent field providing 'useful knowledge' (answering questions such as 'how does one become an entrepreneur?' or 'which support measures do SMEs need?')

There are several reasons for such a state of affairs. These include: i) the weakness of the market economy overall; ii) the limited receptivity to ideas that were developed by observing entrepreneurship in a dynamic, developed economy and 'the dominance of "unproductive entrepreneurship"'; iii) the very limited readiness of business schools and management programmes to pursue their own research projects in the field of entrepreneurship; iv) lack of research funding, etc. (for more detail, see [Chepurenko, 2013b]).

What are the most pressing areas of entrepreneurship to be explored by Russian researchers in the first instance? Below we summarize our recommendations as a detailed discussion will be the topic of another paper:

- Predatory entrepreneurship as a specific type of entrepreneurial behaviour and its roots (not only path dependence but also some institutional traps which emerged during the transition period);

- Ethnic entrepreneurship of immigrant groups, as well as the role of remittances from immigrants working in Russia as sources of business financing in their home countries;

- Clusters of informal entrepreneurs';

- Formats and mechanisms for hiring and employees' control in Russian entrepreneurial firms (there is empirical evidence suggesting that most Russian firms react to demand constraints in a very different manner than firms in established markets; yet, the strategies of labour relations used by Russian firms have been studied much less);

- Diversity of forms and levels of entrepreneurial activity in different contexts and types of settlements (contemporary urban agglomerations, big industrial centres, medium and small sized towns with tightly knit networks of just a few entrepreneurs, and rural areas with a developed agricultural economy);

- Innovative entrepreneurship and its constraints at macro-, mezzo- and micro-levels (from the role of the national innovation system to that of higher schools and academia in promoting entrepreneurship);

- Social entrepreneurship and its future prospects in a lower-income, individualistic society such as that in Russia.

Moreover, a developed academic community with the appropriate institutions, with a suitably formalized status, and endowed with effective mechanisms for self-renewal such as graduate-level university programmes, is needed. However, to develop entrepreneurship research, a radical transformation of the socio-economic environment toward an entrepreneurially friendly ecosystem is needed, as well as major changes within the educational and research systems. This includes, for example, establishing entrepreneurial universities, which could exist within the framework of a national innovation system, in turn based on a triple helix model. In the current state of Russia's society, entrepreneurship research will remain marginalized.

\footnotetext{
1 The semi-closed economy of the former 'Cherkizon' market in the centre of the capital city became a motivating factor for new federal level policy; meanwhile, clusters of shoemaking, textiles, and handicrafts industries in some republics of the North Caucasus, which have very specific types of local entrepreneurial ecosystems are not subjects of entrepreneurship research.
} 


\section{Conclusion}

Entrepreneurship research is (still) challenging, as it has many open questions and opportunities to develop one's own career trajectories and intervene in related areas.

Given that entrepreneurship practices are changing over time, entrepreneurship researchers should be also prepared to change. They should be ready to consider studying new areas, new actors who become entrepreneurs in the $21^{\text {st }}$ century, and master new research designs and methods.

First, a broader view of entrepreneurship enables researchers to open up possibilities for studying domains that were previously never accepted as areas of entrepreneurship research. It also means that it is possible to define entrepreneurship theory as a specific discipline rather than as part of any of the 'bigger' social disciplines such as economics, management, or sociology. If entrepreneurship research were to insist on a narrower definition (the creation of new organizations, or just of small business), it would not only reduce the possibilities for discovering new and promising research directions, but it would also confine it as a sub-field of one of the more traditional disciplines.

Second, a major geographical and societal shift should occur in prospective entrepreneurship research. This shift would reflect the fact that business is developing not only within the well-studied Western contexts but also (perhaps even to a greater extent) within the very different environmental and societal constraints and pre-conditions found in developing countries, in giant markets such as China and India, and in 'transitional' societies.

Third, it becomes not only possible but also obligatory to undertake cross-country, comparative analyses of entrepreneurship that are less formal, yet more substantial. That means researchers should treat entrepreneurship contextually, and avoid making superficial comments and policy recommendations.

Fourth, as new social strata and cohorts are increasingly engaged in entrepreneurial activity, they should be studied by entrepreneurship research; their backgrounds and previous experience, specific sets of entrepreneurial resources, aspirations and traits, and strategies of entrepreneurial action. Such an approach would open up more possibilities for representatives of social anthropology, ethnography, and cultural studies to participate in entrepreneurship research.

Fifth, the development of new technologies for data computing, storage and analysis will enable researchers to turn away from expensive surveys in some cases. Social media will bring new possibilities for enactive longitudinal research techniques to track in detail changes in both peoples' minds as well as entrepreneurial practices over time.

\section{References}

Aidis R., Estrin S., Mickiewicz T. (2010) Institutions, finance and the level of development: The impact on entrepreneurship in transition. Review of Economics and Institutions, vol. 1, no 1, Article 4. DOI: 10.5202/rei.vli1.4. Available at: http://www.rei.unipg.it/rei/article/view/4, accessed 12.11.2014.

Audretsch D.B., Thurik A.R. (2000) Capitalism and democracy in the 21st century: From the managed to the entrepreneurial economy. Journal of Evolutionary Economics, vol. 10, no 1-2, pp. 17-34.

Austin J., Stevenson H., Wei-Skillern J. (2006) Social and commercial entrepreneurship: Same, different, or both? Entrepreneurship Theory and Practice, vol. 30, no 1, pp. 1-22.

Baki Adas E. (2006) The making of entrepreneurial Islam and the Islamic spirit of Capitalism. Journal for Cultural Research, vol. 10, no 2, pp. 113-137.

Batjargal B. (2006) The dynamics of entrepreneurs' networks in a transitioning economy: The case of Russia. Entrepreneurship \& Regional Development, vol. 18, no 4, pp. 305-320.

Baumol W. (1990) Entrepreneurship: Productive, unproductive, and destructive. The Journal of Political Economy, vol. 98 , no 5, pp. 893-921.

Belleflamme P., Lambert Th., Schwienbacher A. (2013) Individual crowdfunding practices. Venture Capital, vol. 15, no 4, pp. 313-333. 
Bögenhold D., Heinonen J., Akola E. (2014) Entrepreneurship and independent professionals: Social and economic logics. International Advances in Economic Research, vol. 20, pp. 295-310.

Busenitz L.B., West III G.P., Shepherd D., Nelson T., Chandler G.L., Zacharakis A. (2003) Entrepreneurship research in emergence: Past trends and future directions. Journal of Management, vol. 29, no 3, pp. 285-308.

Cannon H.M., Smith J.A., Williams D.L. (2007) A Data-overlay approach to synthesizing single-source data. Journal of Advertising, vol. 36, no 4, pp. 7-18.

Carlsson B., Braunerhjelm P., McKelvey M., Olofsson Ch., Persson L., Ylinenpää H. (2013) The evolving domain of entrepreneurship research. Small Business Economics, vol. 41, pp. 913-930.

Chepurenko A., Yakovlev A. (2013) Teoriya predprinimatel'stva: vazhnost' konteksta [Entrepreneurship theory: The importance of the context]. Rossiiskii zhurnal menedzhmenta [Russian Management Journal], no 2, pp. 51-60 (in Russian).

Chepurenko A. (2013) Predprinimatel'stvo kak sfera sotsial'hykh issledovanii: Rossia i mezhdunarodnyi opyt [Entrepreneurship as a sphere of social research: Russia and international experience]. Sotsiologicheskie issledovaniya, no 9, pp. 32-41 (in Russian).

Chepurenko A. (2014) Informal entrepreneurship under transition: Causes and specific features. Soziologie des Wirtschaftlichen: Alte und neue Fragen, Wiesbaden: Springer Verlag, pp. 361-381.

Choi N., Majumdar S. (2014) Social entrepreneurship as an essentially contested concept: Opening a new avenue for systematic future research. Journal of Business Venturing, vol. 29, no 3, pp. 363-376.

Cooke M., Buckley N. (2008) Web 2.0, social networks and the future of market research. International Journal of Market Research, vol. 50, no 2, pp. 267-292.

Curran J., Blackburn R. (2001) Older people and the enterprise society: Age and self-employment propensities. Work, Employment and Society, vol. 15, no 4, pp. 889-902.

Dacin P.A., Dacin M.T., Matear M. (2010) Social entrepreneurship: Why we don't need a new theory and how we move forward from here. Academy of Management Perspectives, vol. 24, no 3, pp. 37-57.

Dahl S. (2010) Current themes in social marketing research: Text-mining the past five years. Social Marketing Quarterly, vol. 16, no 2, pp. 128-136.

Dana L.-P. (2007) Asian Models of Entrepreneurship - From the Indian Union and the Kingdom of Nepal to the Japanese Archipelago: Context, Policy and Practice, Canterbury: University of Canterbury.

Davidsson P., Wiklund J. (2001) Levels of analysis in entrepreneurship research: Current practice and suggestions for the future. Entrepreneurship Theory \& Practice, vol. 25, no 4, pp. 81-99.

DiMaggio P.J. (1988) Interest and agency in institutional theory. Institutional patterns and organizations: Culture and environment (ed. L. Zucker), Cambridge, MA: Ballinger, pp. 3-21.

Ding L. (1994) Entrepreneurship in Suppressed Markets. New York: Garland Publishers.

Dyer W.G. Jr (1994) Toward a theory of entrepreneurial careers. Entrepreneurship: Theory and Practice, vol. 19, no 2, pp. 7-21.

Earle J., Sakova Z. (2000) Business start-ups or disguised unemployment? Evidence on the character of self employment from transition economies. Labour Economics, vol. 7, pp. 575- 601.

Eisenstadt S.N. (1980) Cultural orientations, institutional entrepreneurs and social change: Comparative analyses of traditional civilizations. American Journal of Sociology, vol. 85, pp. 840-869.

Elfakhani S., Ahmed Z.U. (2013) Philosophical basis of entrepreneurship principles within an Islamic ethical framework. Journal of Transnational Management, vol. 18, no 1, pp. 52-78.

Engelen A., Heinemann F., Brettel M. (2009) Cross-cultural entrepreneurship research: Current status and framework for future studies. Journal of International Entrepreneurship, vol. 7, pp. 163-189.

Feige E.L. (1997) Underground Activity and Institutional Change: Productive, Protective and Predatory Behavior in Transition Economies. Transforming Post-Communist Political Economies (eds. J.M. Nelson, C. Tilley, L. Walker), Washington, D.C.: National Academy Press, pp. 21-35.

Fick D.S. (2002) Entrepreneurship in Africa: A Study of Successes, Westport: CT: Quorum books, Greenwood Press.

Fick D.S. (2014) African Entrepreneurs in the 21st Century, Their Stories of Success, Accra: Excellent Publishing and Print.

Fletcher D.E. (2011) A curiosity for contexts: Entrepreneurship, enactive research and autoethnography. Entrepreneurship \& Regional Development, vol. 23, no 1/2, pp. 65-76.

Folmer H., Dutta S., Oud H. (2010) Determinants of rural industrial entrepreneurship of farmers in West Bengal: A Structural equations approach. International Regional Science Review, vol. 33, no 4, pp. 367-396.

Fraser S., Bhaumik S.K., Wright M. (2015) What do we know about entrepreneurial finance and its relationship with growth? International Small Business Journal, vol. 33, no 1, pp. 70-88.

Frydrych D., Bock A.J., Kinder T., Koeck B. (2014) Exploring entrepreneurial legitimacy in reward-based crowdfunding. Venture Capital, vol. 16, no 3, pp. 247-269.

Gartner W.B. (1988) 'Who is an entrepreneur' is the wrong question. American Small Business Journal, vol. 12, no 4, pp. 11-31.

Greenwood R., Suddaby R. (2006) Institutional entrepreneurship in mature fields: The big five accounting firms. The Academy of Management Journal, vol. 49, no 1, pp. 27-48. 
Hall J.K., Daneke G.A., Lenox M.J. (2010) Sustainable development and entrepreneurship: Past contributions and future directions. Journal of Business Venturing, vol. 25, no 5, pp. 439-448.

Hargroves K., Smith M.H. (2005) The Natural Advantage of Nations: Business Opportunities, Innovation and Governance in the 21st Century, London: Earthscan, James and James Publishing.

Haskell J., Linds W., Ippolito J. (2002) Opening spaces of possibility: The Enactive as a qualitative research approach. Forum: Qualitative Social Research, vol. 3, no 3, pp. 140-161.

Herrington M., Kelley D. (2013) African entrepreneurship 2012: Sub-Saharan African Regional Report, Ottawa: IDRC.

HSE (2013) Sovremennye klassiki teorii predprinimatel'stva. Lauteaty mezhdunarodnoi premii za vklad v issledovaniya predprinimatelstva i malogo biznesa (1996-2010) [Contemporary classics of the entrepreneurship theory. Laureates of the Global entrepreneurship award (1996-2010)] (ed. A. Chepurenko), Moscow: HSE (in Russian).

Ireland R.D., Reutzel Ch.R., Webb J.W. (2005) Entrepreneurship research in 'AMJ': What has been published, and what might the future hold? The Academy of Management Journal, vol. 48, no 4, pp. 556-564.

Johannisson B. (2011) Towards a practice theory of entrepreneuring. Small Business Economics, vol. 36, no 2, pp. 135-150.

Jonas A., Lai S., Root G., Warriner R. (2013) Not exactly Silicon Valley: China's distinct brand of entrepreneurship. Available at: http://knowledge.wharton.upenn.edu/article/exactly-silicon-valley-chinas-distinct-brand-entrepreneurship/, accessed 27.03.2015.

Khanna T. (2008) Billions of Entrepreneurs: How China and India Are Reshaping Their Futures — and Yours, Cambridge, MA: Harvard Business School Press.

Kirzner I. M. (1998) Creativity and/or Alertness: A Reconsideration of the Schumpeterian Entrepreneur. The Review of Austrian Economics, vol. 11, no 12, pp. 5-17.

Kiss A.N., Danis W.M., Cavusgil S.T. (2012) International entrepreneurship research in emerging economies: A critical review and research agenda. Journal of Business Venturing, vol. 27, no 2, pp. 266-290.

Koster S., Kumar Rai S. (2008) Entrepreneurship and economic development in a developing country: A case study of India. Journal of Entrepreneurship, vol. 17, no 2, pp. 117-137.

Kuhn T.S. (1962) The Structure of Scientific Revolutions (1st ed.), Chicago, IL: University of Chicago Press.

Lehner O.M., Nicholls A. (2014) Social finance and crowdfunding for social enterprises: A public-private case study providing legitimacy and leverage. Venture Capital, vol. 16, no 3, pp. 271-286.

Liao D., Sohmen P. (2001) The development of modern entrepreneurship in China. Stanford Journal of East Asian Affairs, vol. 1, pp. 27-33.

Lyon F., Sepulveda L. (2009) Mapping social enterprises: Past approaches, challenges and future directions. Social Enterprise Journal, vol. 5, no 1, pp. 83-94.

Maguire S., Hardy C., Lawrence T. (2004) Institutional entrepreneurship in emerging fields: HIV/AIDS treatment advocacy in Canada. The Academy of Management Journal, vol. 47, no 5, pp. 657-679.

Mair J., Marti I. (2006) Social entrepreneurship research: A source of explanation, prediction, and delight. Journal of World Business, vol. 41, no 1, pp. 36-44.

Mallett O., Wapshott R. (2015) Making sense of selfemployment in late career: Understanding the identity work of olderpreneurs. Work, Employment \& Society, vol. 1, pp. 1-17.

McClelland D. (1961) The Achieving Society, Princeton, NJ: Van Nostrand.

Monsen E., Mahagaonkar P., Dienes Chr. (2012) Entrepreneurship in India: The question of occupational transition. Small Business Economics, vol. 39, pp. 359-382.

Naudé W. (2010) Entrepreneurship, developing countries, and development economics: New approaches and insight. Small Business Economics, vol. 34, no 1, pp. 1-12.

Nightingale P., Coad A. (2013) Muppets and gazelles: Political and methodological biases in entrepreneurship research. Industrial and Corporate Change, vol. 23, no 1, pp. 113-143.

North D., Wallis J., Weingast B. (2010) Violence and social orders: A conceptual framework for interpreting recorded human history. Population and Development Review, vol. 36, no 4, pp. 841-843.

Nunan D., di Domenico M.L. (2013) Market research and the ethics of big data. International Journal of Market Research, vol. 55 , no 4 , pp. $2-13$.

Ovaska T., Sobel R. (2005) Entrepreneurship in Post-Socialist economies. Journal of Private Enterprise, vol. 21, no 1, pp. 8-28.

Parrish B.D. (2010) Sustainability-driven entrepreneurship: Principles of organization design. Journal of Business Venturing, vol. 25, no 5, pp. 510-523.

Patzelt H., Shepard D.A. (2011) Recognizing opportunities for sustainable development. Entrepreneurship Theory and Practice, vol. 35, no 4, pp. 631-652.

Petrescu M. (2013) Marketing research using single-item indicators in structural equation models. Journal of Marketing Analytics, vol. 1, no 2, pp. 99-117.

Phillips N., Tracey P. (2007) Opportunity recognition, entrepreneurial capabilities and bricolage: connecting institutional theory and entrepreneurship in strategic organization. Strategic Organization, vol. 5, no 3, pp. 313-320.

Rehn A., Taalas S. (2004) Znakomstva i svyazi (Acquaintances and connections): Blat, the Soviet Union, and mundane entrepreneurship. Entrepreneurship and Regional Development, vol. 16, no 3, pp. 235-250. 
Reynolds P., Bosma N., Autio E., Hunt S., De Bono N., Servais I., Lopez-Garcia P., Chin N. (2005) Global Entrepreneurship Monitor: Data collection, design and implementation 1998-2003. Small Business Economics, vol. 24, no 3, pp. $205-231$.

Rona-Tas A., Sagi M. (2005) Entrepreneurship and self-employment in transition economies. Entrepreneurship (Research in the Sociology of Work), vol. 1, pp. 279-310.

Sarasvathy S. (2001) Causation and effectuation: Toward a theoretical shift from economic inevitability to entrepreneurial contingency. Academy of Management Review, vol. 26, no 2, pp. 243-263.

Sauka A., Welter F. (2007) Productive, unproductive and destructive entrepreneurship in an advanced transition setting: The example of Latvian small enterprises. Empirical entrepreneurship in Europe, Cheltenham: Edward Elgar, pp. 87-111.

Scase R. (2003) Entrepreneurship and Proprietorship in Transition: Policy Implications for the SME Sector. Small and Medium Enterprises in Transitional Economies (eds. R. McIntyre, B. Dallago), London: Palgrave Macmillan, pp. 64-77.

Schumpeter J.A. (1936) Theory of Economic Development, Cambridge, MA: Harvard University Press.

Shane S. (2009) Introduction to the focused issue on the biological basis of business. Organizational Behavior and Human Decision Processes, vol. 110, no 2, pp. 67-69.

Shane S., Venkataraman S. (2000) The promise of entrepreneurship as a field of research. Academy of Management Review, vol. 25, no 1, pp. 217-226.

Shane S., Venkataraman S. (2001) Entrepreneurship as a field of research: A Response to Zahra and Dess, Singh, and Erikson. The Academy of Management Review, vol. 26, no 1, pp. 13-16.

Short J.C., Ketchen D.J. Jr, Combs J.G., Ireland R.D. (2010) Research methods in entrepreneurship: Opportunities and challenges. Organizational Research Methods, vol. 13, no 1, pp. 6-15.

Simons B.B. (2012) What Africa's entrepreneurs can teach the world. Harvard Business Review, March 5.

Smallbone D., Welter F. (2001) The distinctiveness of entrepreneurship in transition economies. Small Business Economics, vol. 16, no 4, pp. 249-262.

Smallbone D., Welter F. (2009) Entrepreneurship and Small Business Development in Post-Socialist Economies, London: Routledge.

Spicer A., McDermott G.A., Kogut B. (2000) Entrepreneurship and privatization in Central Europe: The tenuous balance between destruction and creation. The Academy of Management Review, vol. 25, no 3, pp. 630-649.

Sridharan S., Maltz E., Viswanathan M., Gupta S. (2014) Transformative subsistence entrepreneurship: A Study in India. Journal of Macromarketing, vol. 34, no 4, pp. 486-504.

Steyaert Ch., Landström H. (2011) Enacting entrepreneurship research in a pioneering, provocative and participative way: On the work of Bengt Johannisson. Small Business Economics, vol. 36, no 2, pp. 123-134.

Tirunillai S., Tellis G.J. (2014) Mining marketing meaning from online chatter: Strategic brand analysis of Big Data using latent Dirichlet allocation. Journal of Marketing Research, vol. 51, no 4, pp. 463-479.

Tomczak A., Brem A. (2013) A conceptualized investment model of crowdfunding. Venture Capital, vol. 15, no 4, pp. 335-359.

Torri M.C., Martinez A. (2014) Women's empowerment and micro-entrepreneurship in India: Constructing a new development paradigm? Progress in Development Studies, vol. 14, no 1, pp. 31-48.

Uhlaner L.M. (2003) Trends in European research on entrepreneurship at the turn of the century. Small Business Economics, vol. 21, no 4, pp. 321-328.

Uhlaner L.M., Thurik A.R. (2007) Post-materialism: A cultural factor influencing total entrepreneurial activity across nations. Journal of Evolutionary Economics, vol. 17, no 2, pp. 161-185.

Vickerstaff S., Cox J. (2005) Retirement and risk: The individualisation of retirement experiences? The Sociological Review, vol. 53, no 1, pp. 77-95.

Welter F. (2011) Contextualizing entrepreneurship - Conceptual challenges and ways forward. Entrepreneurship Theory and Practice, vol. 35, no 1, pp. 165-184.

Welter F., Smallbone D. (2011) Institutional perspectives on entrepreneurial behavior in challenging environments. Journal of Small Business Management, vol. 49, no 1, pp. 107-125.

Wennekers S., Thurik R. (1999) Linking entrepreneurship and economic growth. Small Business Economics, vol. 13, no 1, pp. 27-55.

Wong J., Rong M., Mu Y. (1995) China's Rural Entrepreneurs, Singapore: Times Academic Press.

Xheneti M., Blackburn R.A. (2011) Small Business and Entrepreneurship (SBE): An Analysis of Publications and Implications for the Development of the Field. Challenges and Controversies in Management Research (Routledge Advances in Management and Business Studies) (eds. B. Lee, C.Cassell), London: Routledge, pp. 367-388.

Zhang J., Zhang L., Rozelle S., Boucher S. (2006) Self-employment with Chinese characteristics: The forgotten engine of rural China's growth. Contemporary Economic Policy, vol. 24, no 3, pp. 446-458. 